\title{
КРИМІНАЛЬНІ ПРОСТУПКИ ЯК СПЕЦИФІЧНИЙ ВИД КРИМІНАЛЬНИХ ПРАВОПОРУШЕНЬ
}

\author{
АЛЕКСЕСВА-ДАНИЛЕНКО Юлія Володимирівна - аспірант Харківського \\ національного університету внутрішніх справ \\ DOI 10.32782/LAW.UA.2021.3.17
}

У числі ключових проблем сучасного кримінального законодавства Украӥни і особливо впродовж двох останніх десятиліть виникає проблема лібералізащї кримінальної відповідальності, включаючи декриміналізачію окремих видів кримінальних правопорушень, зниження кримінально-правових санкиій за окремі протиправні діяння.

Особливої актуальності набрала реалізачія приниипу справедливості покарання за скоєне кримінальне правопорушення. Перебування в місиях позбавлення волі, судимість і ї наслід$\kappa и$, пов'язані з правовими і соціальними обмеженнями, надають, як правило, негативний вплив на особистість засудженого. Реальне позбавлення волі призводить не тільки до деформачіӥ особистості засудженого, а й позначається на його подальшу долю. Це пов'язано, насамперед, з тим, шо найчастіше сам фбакт судимості, за будь-яке за ступенем тяжкості кримінальне правопорушення сприймається суспільною свідомістю негативно, з відповідними наслідками, як-от: неможливості влаштуватися на роботу, ігнорування (відсторонення) такої особи суспільством тощо, що в результаті нерідко призводить до повторного вчинення кримінального правопорушення.

В останні роки спостерігається стійка тендениія зростання показника засуджених за вчинення кримінальних правопорушень невеликої тяжкості від загального числа засуджених. Таким чином, сучасна структура судимості характеризується тим, що практично кожна друга особа засуджується за кримінальне правопорушення невеликої тяжкості. Звідси виникла необхідність у призначенні, справедливого покарання, яке максимально сприятиме виправленню, а не деббормащй особистості засудженого.

Нова категорія правопорушень - кримінальний проступок займає проміжну ланку між адміністративним правопорушенням $i$ злочинами та дозволяе більш точно класибікувати кримінальні правопорушення за ступенем їх суспільної небезпеки, детально диферениіювати покарання для засудженого, відповідно до приниипів справедливості та гуманізму.

Ключові слова: кримінальні правопорушення, кримінальні проступки, законодавство, покарання.

\section{Постановка проблеми}

В Україні вживаються заходи щодо гуманізації кримінального законодавства, що проявляється у вигляді декриміналізації кримінальних правопорушень, введення складів окремих правопорушень 3 адміністративної преюдиції, застосування покарань, альтернативних позбавленню волі i розширення сфери застосування інституту звільнення від кримінальної відповідальності.

1 липня 2020 року набув чинності Закон України «Про внесення змін до деяких законодавчих актів України щодо спро- 


\section{Кримінальне право, кримінальний процес та криміналістика}

щення досудового розслідування окремих категорій кримінальних правопорушень» [1], яким зокрема внесені зміни в Кодекс України про адміністративні правопорушення, Кримінальний Кодекс України та Кримінальний процесуальний кодекс України. Ці зміни пов'язані з виділенням 3 числа кримінальних правопорушень невеликої тяжкості діянь, за вчинення яких Закон не передбачає покарання у вигляді позбавлення волі і визначає їх кримінальними проступками. Інститут кримінального проступку на сьогодні, залишається не достатньо урегулюваною правовою категорією як у теорії кримінального права, так і на практиці його реалізації, що обумовлює актуальність додаткового дослідження.

\section{Стан дослідження проблеми}

Теоретичні питання, пов'язані з правовою природою інституту кримінального проступку, визначення загальних підходів їх законодавчого врегулювання, диференціацією правопорушень та інших діянь як виду кримінальних проступків, уже досліджувались окремими вченими, зокрема, А.А. Васильєв, В.К. Грищук, О.П. Горпинюк, І.О. Зінченко, О.М. Аитвинов, В.Б. Харченко, В.П. Емельянов, І.В. Красницький, О.С. Пироженко, Д.С. Азаров, Н.О. Гуторова, О.О. Дудоров, К.П. Задоя, В.І. Тютюгін, Є.Л. Стрельцов, П.Л. Фріс, М.І. Хавронюк, В.О. Навроцький, та інші. Дослідження цих учених зробили значний внесок у теоретичні аспекти розуміння кримінального проступку, але з урахуванням урегулювання цього інституту у теорії кримінального права та застосування його на практиці, зміни законодавства виникає необхідність додаткового розгляду норм чинного законодавства щодо кримінального проступку.

Мета дослідження полягає у дослідженні особливостей кримінального проступку як специфічного виду кримінальних правопорушень.

\section{Наукова новизна дослідження}

Внесення змін до чинного законодавства України у аспекті кримінальних правопорушень сприяє їх розподілу на кри- мінальні проступки та злочини. Крім того, 3'являється новий суб'єкт кримінально-процесуальної діяльності - дізнавач, нові види доказування при розслідуванні кримінального проступку тощо. Таким чином, виникає необхідність дослідження та удосконалення чинних нормативно-правових норм, направлених на застосування відповідальності до особи, яка вчинила кримінальний проступок.

\section{Виклад основного матеріалу}

3 прийняттям Закону України «Про внесення змін до деяких законодавчих актів України щодо спрощення досудового розслідування окремих категорій кримінальних правопорушень», до Кримінального кодексу України введено нове поняття - кримінальний проступок. У частині 2 ст. 12 КК України визначено, що кримінальним проступком є передбачене цим Кодексом діяння (дія чи бездіяльність), за вчинення якого передбачене основне покарання у виді штрафу в розмірі не більше трьох тисяч неоподатковуваних мінімумів доходів громадян або інше покарання, не пов'язане з позбавленням волі [2].

До прийняття вищезазначеного Закону у КК України існувало понад 90 складів кримінальних правопорушень невеликої тяжкості, за вчинення яких не передбачено покарання у вигляді позбавлення волі, а значить, усі вони $з$ прийняттям цього Закону та внесенням змін до КК України стали кримінальними проступками.

Проблема кримінального проступку обговорюється вченими-юристами вже понад півстоліття. Ще у 60-і р.p. минулого століття Н.Ф. Кузнєцова вказувала на необхідність, при класифікації діянь за ступенем суспільної небезпечності, об’єднати в єдину групу кримінальні правопорушення невеликої та ряд кримінальних правопорушень середньої тяжкості. Виходячи 3 цього, було запропоновано розділити суспільно небезпечні діяння на злочини та кримінальні проступки, які представляють істотно меншу суспільну небезпеку. Ця міра дозволила б продовжити диференціацію кримінальної відповідальності. 
Досвід узаконення незначних кримінальних правопорушень за типом кримінальних проступків існуе і за кордоном, зокрема, в США, Німеччині, Польщі, Латвії, Швеції та інших країнах. У більшості держав кримінальні кодекси диференціюють кримінально-правові діяння на дві або три категорії і самі малозначні кримінальні правопорушення часто визначають як кримінальні проступки.

I.B. Ковтун висловив думку, що запровадження інституту кримінального проступку хоча й здатне зблизити національне законодавство про кримінальну відповідальність iз законодавством країн Европейського Союзу, проте потребує свого подальшого доопрацювання на концептуальному рівні 3 урахуванням сучасних досягнень науки кримінального, кримінального процесуального та адміністративного права, а також тенденцій гуманізації законодавства України про кримінальну відповідальність [3].

B.I. Борисов, В.І. Тютюгін, А.М. Демидова висловили думку про те, що запровадження кримінального проступку до національного законодавства України має охоплювати і завдання, які вона виконує. Серед таких основних завдань науковці окреслили наступні: гуманізація та оптимізація кримінального законодавства; удосконалення кримінального процесуального законодавства шляхом запровадження спрощеної процедури досудового розслідування та судового розгляду матеріалів кримінального провадження щодо кримінальних проступків; пом'якшення кримінальних покарань шляхом удосконалення санкцій за вчинення кримінальних проступків; впровадження в законодавство України рекомендацій Європейського Суду з прав людини та міжнародних стандартів у сфері боротьби зі злочинністю [4].

Термін «кримінальний проступок» вдало підкреслює специфіку кримінальних правопорушень, за які замість традиційного кримінального покарання можуть бути винесені інші заходи суспільного впливу. Ці діяння, залишаючись у цілому кримінальними правопорушеннями, разом $з$ тим носять попереджувальний характер, даючи засуджено- му реальний шанс на виправлення. Таким чином, передбачається, що кримінальний проступок займає проміжну «середину» між адміністративними та кримінальними протиправними діяннями.

Щодо суті кримінального проступку в юридичній літературі висловлені полярні позиції. Так, Б.Я. Гаврилов і Е.В. Рогова відносять кримінальний проступок до різновиду кримінальних правопорушень. На їхню думку, порівняно 3 кримінальними правопорушеннями кримінальний проступок володіє меншим ступенем суспільної небезпечності і тягне менш суворе покарання, що виключає судимість [5, с. 41]. Автори виділяють ряд ознак кримінального проступку, які потребують коментаря, сенс першої ознаки зводять до обгрунтування кримінального проступку як різновиду кримінальних правопорушень. Вони фактично ототожнюють кримінальний проступок 3 кримінальними правопорушеннями, визнаючи в ньому наявність усіх суттєвих проявів злочинного діяння: суспільної небезпечності, винності, заборонності кримінальним законом і погрози покаранням.

Друга ознака, 3 точки зору зазначених дослідників, полягає в тому, що кримінальний проступок у порівнянні зі злочином має меншу за ступенем суспільну небезпечність. Ця ознака вступає в явне протиріччя з попереднім. Будучи видом злочинного діяння, кримінальний проступок не може володіти іншими якісними і кількісними параметрами суспільної небезпеки, що виходять за межі розуміння суспільної небезпечності кримінальних правопорушень.

Третя ознака стосується специфіки юридичних наслідків вчинення кримінального проступку. Кримінальний проступок повинен передбачати можливість застосування певного кримінального покарання, виключаючи судимість.

На підставі вищевикладеного можна зробити висновок про те, що кримінальний проступок - це особливий вид кримінальних правопорушень, що відрізняється як від адміністративних проступків, так і від власне кримінальних правопорушень. Його специфіка полягає у відносно невисокому рівні суспільної небезпеки, яка обумовлює необ- 


\section{Кримінальне право, кримінальний процес та криміналістика}

хідність визначення особливого режиму відповідальності.

Оскільки кримінальний проступок має у своїй основі попереджувальний характер, то і санкції для кримінальних проступків також повинні бути особливі, а саме - змішані: «наполовину» покарання, «наполовину» заходи громадського впливу. Передбачається новий вид звільнення від кримінальної відповідальності за вчинення кримінального проступку - це застосування інших заходів кримінально-правового характеру. Під ними можуть розумітися, наприклад, сукупність судового штрафу і громадських робіт, або сукупність інших видів покарань, не пов’язаних з ізоляцією засудженого від суспільства. Це може бути: штраф, позбавлення права обіймати певні посади або займатися певною діяльністю, громадські роботи та виправні роботи.

Однак, для застосування цього виду звільнення від кримінальної відповідальності встановлюються наступні умови:1) кримінальний проступок повинен бути вчинений вперше і відноситись, як кримінальне правопорушення, до категорії невеликої або середньої тяжкості; 2) заподіяна кримінальним проступком шкода має бути відшкодована.

Чинний Кримінальний кодекс України визначає кримінальне правопорушення (ч. 1 ст. 11), яке розділяється на такі види: злочин та кримінальний проступок. Таким чином, кримінальне правопорушення виступає родовим поняттям по відношенню до «злочину» та «кримінального проступку». А отже, наприклад, якщо особа вчинила кримінальне правопорушення, передбачено ч. 1 ст. 185 КК України, то таке діяння є кримінальним проступком, а ч.ч. 2-5 ст. 185 КК України - злочином. Це досить важливо для кримінально-правових наслідків вчинення кримінального правопорушення. У свою чергу, злочин та кримінальний проступок повинен різнитись за видом та мірою покарання.

Доречним є зауваження I.B. Красницького та О.П. Горпинюк, що формальне перейменування злочину на кримінальне правопорушення у низці випадків видається невиправданим (зокрема, у ст. 107 КК України, адже умовно-дострокове звільнення може застосовуватися лише до неповнолітніх осіб, які відбули певну частку від призначеного строку покарання у виді позбавлення волі за нетяжкий, тяжкий чи особливо тяжкий злочин; можливість умовно-дострокового звільнення за вчинення кримінального проступку не передбачена) [6, с. 18].

Як уже зазнчалось, Законодавець у ч. 2 ст. 12 КК України закріпив поняття кримінальний проступок. Крім того, вніс зміни щодо визначення ступеня тяжкості вчиненого кримінального правопорушення. Ч. 3 ст. 12 КК України встановив, що злочини поділяються на нетяжкі, тяжкі та особливо тяжкі [2]. Тепер кримінальні правопорушення середньої тяжкості є кримінальними проступками.

Таким чином, кримінальні правопорушення за ступенем тяжкості поділяються на: 1) кримінальні проступки; 2) злочини невеликої тяжкості; 3) тяжкі злочини;4) особливо тяжкі злочини.

Закон України «Про внесення змін до деяких законодавчих актів України щодо спрощення досудового розслідування окремих категорій кримінальних правопорушень» торкнувся і до змін щодо проведення кримінальної процесуальної діяльності, виділивши нового її суб'єкта - дізнавача, який i проводить розслідування кримінальних проступків. П. 4-1 ч. 1 ст. 3 КПК України закріплюе поняття дізнавач - службова особа підрозділу дізнання органу Національної поліції, органу безпеки, органу, що здійснює контроль за додержанням податкового законодавства, органу Державного бюро розслідувань, у випадках, установлених цим Кодексом, уповноважена особа іншого підрозділу зазначених органів, які уповноважені в межах компетенції, передбаченої цим Кодексом, здійснювати досудове розслідування кримінальних проступків [7].

На етапі попереднього розслідування органи дізнання виконують специфічну роль. У розслідуванні кримінальних проступків правоохоронні органи представляють собою державні органи, до яких надходить інформація про вчинення кримінального правопорушення. У силу специфіки роботи вони зобов'язані негайно реагувати на факт 
порушення Закону, вживати превентивних заходів, у тому числі кримінального процесуального характеру, тобто діяти як орган дізнання.

Попереднє розслідування включає дві форми: дізнання і попереднє слідство. Перший вид діяльності виконують органи дізнання, а другий - слідчі.

Дізнання ділиться на два типи: 1) у провадженнях, у яких провадження попереднього слідства не обов'язково (самостійне розслідування); 2) у провадженнях 3 обов'язковим досудовим слідством (допоміжна діяльність спеціальних органів по відношенню до слідчого). Незалежно від того, самостійну або допоміжну для слідчих роботу виконують органи дізнання, суттєвих розходжень у процесуальних формах діяльності цих органів немає.

При розслідуванні кримінальних проваджень органи дізнання вживають необхідні оперативно-розшукові, слідчі та інші передбачені кримінальним процесуальним Законом заходи з метою виявлення кримінальних правопорушень і виявлення винних.

Згідно з ч. 3 ст. 38 КПК України дізнання здійснюють підрозділи дізнання або уповноважені особи інших підрозділів:а) органів Національної поліції; б) органів безпеки; в) органів, що здійснюють контроль за додержанням податкового законодавства; г) органів Державного бюро розслідувань; г) Національного антикорупційного бюро України [7].

Начальнику органу дізнання законом наділені наступні повноваження:

- він має право доручати дізнавачу перевірку повідомлення про кримінальні правопорушення і ухвалювати рішення за отриманими результатами;

- при наявності підстави начальник підрозділу дізнання може вилучати матеріали дізнання в одного дізнавача і передавати іншому;

- він може скасовувати постанову дізнавача, визнане незаконним;

- здійснювати інші повноваження, передбачені цим Кодексом (ст. 39-1 КПК України).

Дізнавач має право самостійно проводити слідчі та інші процесуальні дії, крім випадків, коли потрібен дозвіл начальника, судді або прокурора. При виникненні необхідності у проведенні оперативно-розшукових заходів дізнавач може дати оперативним органам доручення, обов'язкове для виконання. Дізнавач зобов'язаний підкорятися вказівкам прокурора і начальника органу дізнання.

Термін дізнання становить один місяць, але при необхідності дізнавач може продовжити його за згодою прокурора.

Внесені зміни у КПК України також торкнулись доказів у кримінальному провадженні. Процесуальні джерела доказів у кримінальних провадженнях про кримінальні проступки, окрім положень ст. 84 КПК України, також є пояснення осіб, результати медичного освідування, висновок спеціаліста, показання технічних приладів і технічних засобів, що мають функції фотоi кінозйомки, відеозапису чи засобів фото- i кінозйомки, відеозапису. Такі процесуальні джерела доказів не можуть бути використані у кримінальному провадженні щодо злочину, окрім як на підставі ухвали слідчого судді, яка постановляється за клопотанням прокурора (ст. 298-1 КПК України) [7].

Законодавець розмежовує джерела доказів за видами кримінальних проваджень, тобто такі, які можна застосовувати під час розслідування злочинів, або ті які застосовуються під час розслідування кримінальних проступків. Aле якщо зіставляти положення ст. 84 КПК України, то стає незрозумілим, які джерела доказів можна застосовувати до того чи іншого виду кримінальних правопорушень. Тому виникає необхідність доповнити ст. 84 КПК України та внести відповідні корегування щодо конкретизації видів кримінальних правопорушень, до яких можна застосовувати відповідні джерела доказів.

\section{Висновки}

Одним із найважливіших напрямків вдосконалення заходів кримінально-правового впливу $є$ диференціація відповідальності за кримінальні правопорушення, які не становлять великої суспільної небезпеки (невеликої тяжкості). Історично сформована міжгалузева диференціація публічної відпо- 


\section{Кримінальне право, кримінальний процес та криміналістика}

відальності на кримінальну та адміністративну є позитивним досягненням кодифікаційного процесу і дозволяє досить ефективно реагувати на зміну характеру і тяжкості асоціальної поведінки як за допомогою криміналізації найбільш небезпечних проявів.

Основні ідеї введення інституту кримінального проступку полягають у тому, щоб: 1) більш точно класифікувати кримінальні правопорушення за ступенем їх суспільної небезпеки; 2) максимально диференціювати покарання для засудженого, зробивши його найбільш справедливим і гуманним;3) звільнити засуджених за кримінальні правопорушення невеликої або середньої тяжкості, які вчинили їх вперше, від порочного інституту судимості, який робить негативний вплив на подальшу долю людини, найчастіше, змусив осіб на вчинення нових кримінальних правопорушень.

Що ж стосується процесуального аспекту розслідування кримінальних проступків, то норми чинного законодавства потребують певних корегувань. На теперішній час деякі норми КПК України містять колізії, що викликає відповідні труднощі під час розслідування кримінальних проступків.

\section{Аітература}

1. Закон України «Про внесення змін до деяких законодавчих актів України щодо спрощення досудового розслідування окремих категорій кримінальних правопорушень». Відомості Верховної Ради (ВВР), 2019, № 17, ст.71.
2. Кримінальний кодекс України. Відомості Верховної Ради України (ВВР), 2001, № 25-26, ст.131.

3. Ковтун I.B. Проблема запровадження у законодавство України інституту кримінального проступку. Науковий вісник Дніпропетровського державного університету внутрішніх справ. 2014. № 2. C. 230-240. URL: file://home/chronos/ueaaccf928500c23a587360f86ccc095ef5679a35/ MyFiles/Downloads/Nvdduvs_2014_2_34.pdf (дата звернення 25.09.2021).

4. Борисов B.I., Тютюгін B.I., Демидова ᄉ.M. Кримінальний проступок: концептуальні засади запровадження до національного законодавства. Вісник Асоціації кримінального права України. 2016, № 2(7). C. 129-142. URL: http://nauka. nlu.edu.ua/ wp-content/uploads/2016/12/06 Borisov.pdf (дата звернення 25.09.2021).

5. Гаврилов Б. Я., Рогова Е. В. Уголовный проступок: концепция развития (мнение ученого и практика) // Публичное и частное право. 2016. № 4. С. 7-45.

6. Красницький I.B., Горпинюк О.П. Запровадження кримінальних проступків: аналіз змін до законодавства. Кримінальне та кримінальне процесуальне законодавство у контексті реформи кримінальної юстиції : матеріали наук.-практ. семінару (31.05.2019 р., м. Аьвів). Аьвів: Аьвів. держ. ун-т внутр. справ. 2019. С. 17-21.

7. Кримінальний процесуальний кодекс України. Відомості Верховної Ради України (ВВР), 2013, № 9-10, № 11-12, № 13, ст.88. 